\title{
Some Properties of Endo-polygalacturonase from Trichosporon penicillatum $\mathrm{SNO}-3^{\dagger}$
}

\author{
Takuo SaKaI, ${ }^{*}$ Minoru OKushima and Masahiko SaWada \\ Department of Agricultural Chemistry, College of Agriculture, \\ University of Osaka Prefecture, Sakal, Osaka 591, Japan
}

Received January 11, 1982

\begin{abstract}
Some properties of the endo-polygalacturonase from Trichosporon penicillatum were investigated. The enzyme showed the highest activity around $\mathrm{pH} 5.0$ and was stable at this $\mathrm{pH}$ up to $50^{\circ} \mathrm{C}$. The enzyme catalyzed the hydrolysis of galacturonic acid oligomers as well as its polymer. The pentamer was degraded to a trimer and a dimer, the tetramer to a trimer and a monomer, and the trimer to a dimer and a monomer, respectively, whereas the dimer was not degraded. The kinetic constant $V_{\max }$ and $K m$ values changed with the substrate chain-length; the $K m$ values tended to decrease, whereas the $V_{\max }$ values tended to increase with increasing chain-length of the substrate. The amino acid residue participating in the active site of the enzyme was studied and it was found to be histidine.
\end{abstract}

There have been many observations on the maceration ability of endo-polygalacturonase and this activity is applied in the production of fruit juice and wines.

Some strains of yeast producing endopolygalacturonase have been found and these enzymes have the ability to clarify a citrus pectin medium. However, the papers on endopolygalacturonases published so far have not dealt with their protopectin-solubilizing activity. In the preceding papers, the authors presented an endo-polygalacturonase from Trichosporon penicillatum having protopectinsolubilizing activity, and demonstrated a new method for pectin production using the enzyme. ${ }^{1 \sim 4)}$

The present paper describes some properties of this endo-polygalacturonase having protopectin-solubiolizing activity produced in a culture filtrate of Trichosporon penicillatum SNO-3.

\section{MATERIALS AND METHODS}

Chemicals. All chemicals, unless otherwise specified, were of Wako Pure Chemicals Industries (Osaka) certified reagent grade. Protopectin was prepared by the method described in the preceding paper. ${ }^{4)}$

Enzyme. The enzyme used in this study was a crystalline preparation which was obtained by the method described in the preceding paper. ${ }^{4)}$

Preparation of oligogalacturonic acids. Oligogalacturonic acids were prepared according to the method described by Nagel et al. ${ }^{5)}$ and isolated by chromatography on a Dowex $1 \times 8(200 \sim 400$ mesh $)$ column. Their purities were confirmed by thin layer chromatography (TLC), and their polymerization degrees were determined from the ratio of total reducing groups to total galacturonic acid molecules. Thin layer chromatography was performed using a cellulose sheet (Kodak Chromato Sheet ${ }^{\circledR}$, the solvent system used was the epiphase from a mixture of ethylacetate-acetic acid-water $=2: 1: 2$ ). The individual galacturonic acid derivatives on TLC were revealed with a periodate-benzidine reagent. ${ }^{6}$ )

Preparation of polygalacturonic acids with various numbers of methoxyl groups. Polygalacturonic acids with various numbers of methoxyl groups were prepared as follows: To $100 \mathrm{ml}$ of $1 \%$ pectin solution was added $100 \mathrm{ml}$ of $0.1 \mathrm{~N} \mathrm{NaOH}$ solution and this mixture was stood at $0^{\circ} \mathrm{C}$ for up to $45 \mathrm{~min}$ (this period depended upon the methoxyl group content of the product). After the reaction, $1 \mathrm{ml}$ of $16 \mathrm{~N}$ acetic acid solution and $600 \mathrm{ml}$ of ethanol were added in that order. The resultant precipitate was collected by centrifugation $(2,000 \times g$ for $20 \mathrm{~min})$ at $5^{\circ} \mathrm{C}$, washed with

$\uparrow$ Studies on the Enzymes Produced by Yeasts. Part IV. For Part III, see ref. 4.

* To whom correspondence should be addressed. 
acetone, dissolved in distilled water, and dialyzed against distilled water overnight. The dialyzed solution was lyophilized and used as the sample.

Enzyme assay. Except for the determination of $\mathrm{Km}$ and $V_{\max }$, enzyme activities were determined by the method described in the preceding paper. ${ }^{4)}$ To determine $\mathrm{Km}$ and $V_{\max }$ values, the enzyme reaction was performed at $37^{\circ} \mathrm{C}$, and the activity was quantified by measuring the release of reducing groups from oligogalacturonic acid using the Somogyi assay method ${ }^{7)}$ with Nelson's arsenomolybdate reagent. $^{8)}$

Photoinactivation of the enzyme. The photoinactivation experiments were performed at $20^{\circ} \mathrm{C}$ with the enzyme solution $(20 \mu \mathrm{g} / \mathrm{ml})$ containing $0.001 \%$ Methylene Blue and $0.05 \mathrm{M}$ Tris- $\mathrm{HCl}, \mathrm{pH} 7.5$, in a $15 \times 150 \mathrm{~mm}$ tube (sample volume of $2 \mathrm{ml}$ ). The test tube containing the enzyme solution was placed $10 \mathrm{~cm}$ from a $150 \mathrm{~W}$ projector.

Analyses. The protein concentration was determined by the method of Lowry et al..$^{9}$ using bovine serum albumin as a standard.

Amino acid analysis was performed on a Hitachi KLA5 Amino Acid Analyzer.

\section{RESULTS}

Effect of $p H$ on activity and stability of the enzyme

The effect of $\mathrm{pH}$ on protopectinase and pectic acid liquefying activities was investigated and the results are shown in Fig. 1. The pH-activity profiles changed depending upon the substrate used, and showed maximum activity around $\mathrm{pH} 5.5$ for protopectinase and around 5.0 for pectic acid liquefying activity, respectively.

The effect of $\mathrm{pH}$ on the stability of the enzyme was investigated by preincubation for $30 \mathrm{~min}$ at $37^{\circ} \mathrm{C}$ in various buffers of $\mathrm{pH} 2$ to 11. The enzyme activity was not lost in the acidic $\mathrm{pH}$ range of 3 to 6 , but the activity was lost remarkably at alkaline $\mathrm{pHs}$ (higher than $\mathrm{pH}$ 7.5) (Fig. 2).

\section{Effect of temperature on activity and stability of the enzyme}

The optimal temperature for enzyme activity changed depending upon the substrate used, being around $50^{\circ} \mathrm{C}$ for pectic acid and $40^{\circ} \mathrm{C}$ for protopectin (Fig. 3). The enzyme was

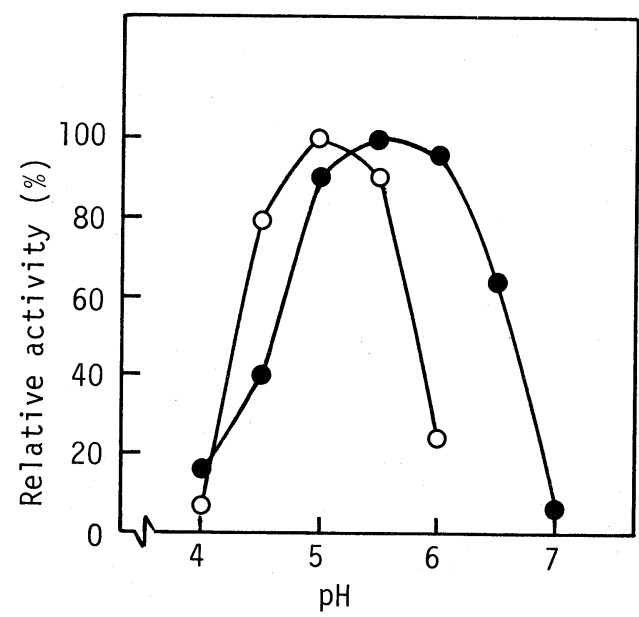

FIG. 1. Effect of $\mathrm{pH}$ on the Enzyme Activity.

The pectic acid liquefying activity was assayed in $0.02 \mathrm{M}$ Macllvaine buffer and protopectinase activity was assayed in $0.02 \mathrm{M}$ acetate buffer ( $\mathrm{pH} 4$ to 5.5 ) and $0.02 \mathrm{M}$ sodium phosphate buffer ( $\mathrm{pH} 5.5$ to 7.0), respectively, under the standard assay conditions. ( ), pectic acid liquefying activity; $(\bigcirc)$, protopectinase activity.

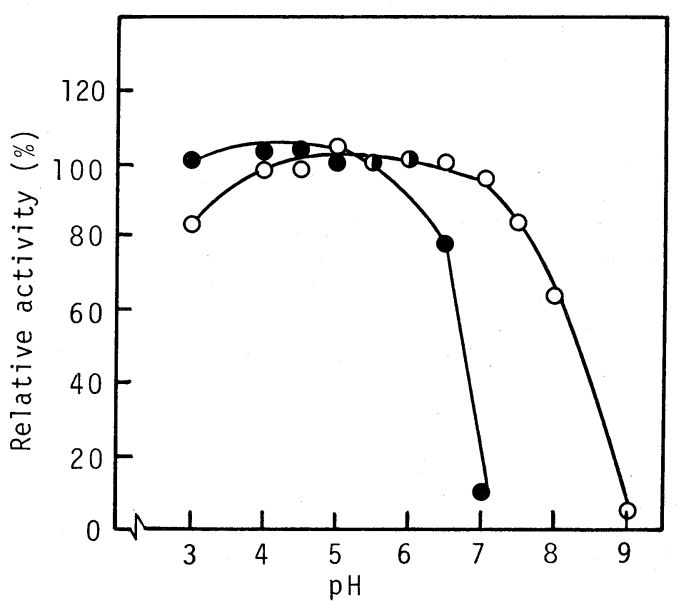

FIG. 2. Effect of $\mathrm{pH}$ on the Enzyme Stability.

The enzyme ( 30 units $/ \mathrm{ml})$ in various buffers $(0.02 \mathrm{M}$ acetate buffer, $\mathrm{pH} 3$ to 5.5 , and $0.02 \mathrm{M}$ sodium phosphate buffer, $\mathrm{pH} 6.0$ to 9.0 ) containing $50 \mu \mathrm{g} / \mathrm{ml}$ bovine serum albumin was incubated at $37^{\circ} \mathrm{C}$ for $30 \mathrm{~min}$, and remaining activities were determined under the standard assay conditions. (O), pectic acid liquefying activity; $(\bigcirc)$, protepectinase activity.

treated for $30 \mathrm{~min}($ at $\mathrm{pH} \mathrm{5.0)}$ at the temperatures indicated in Fig. 4, and then the remaining activity was assayed. The enzyme was 


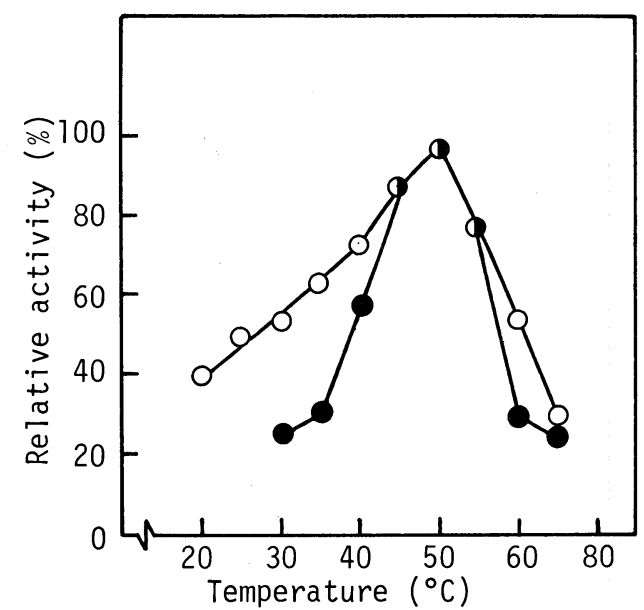

FIG. 3. Effect of Temperature on the Enzyme Activity.

The enzyme activities were assayed at various temperatures $\left(30\right.$ to $\left.60^{\circ} \mathrm{C}\right)$ under the standard assay conditions. $(\bigcirc)$, pectic acid liquefying activity; $(\bigcirc)$, protopectinase activity.

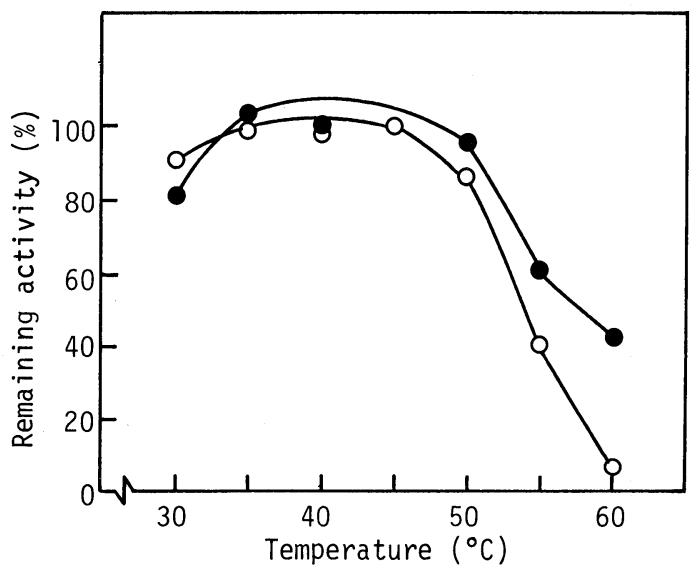

FIG. 4. Effect of Temperature on Stability of the Enzyme.

The enzyme ( 30 units $/ \mathrm{ml}$ ) in $0.02 \mathrm{M}$ acetate buffer, $\mathrm{pH} 5.0$, containing $50 \mu \mathrm{g} / \mathrm{ml}$ bovine serum albumin was kept for 30 min at various temperatures $\left(30\right.$ to $\left.60^{\circ} \mathrm{C}\right)$, and the remaining activities were assayed under the standard assay conditions. (O), pectic acid liquefying activity; $(\bigcirc)$, protopectinase activity.

stable at temperatures lower than $50^{\circ} \mathrm{C}$, but unstable above $55^{\circ} \mathrm{C}$, and lost ist activity remarkably at $60^{\circ} \mathrm{C}$ under the conditions used in this experiment.

Effects of various compounds on enzyme activity The effects of some compounds on enzyme
TABLE I. EFFEct of VARIOUS Compounds ON ENZYME ACTIVITY

Enzyme activity was determined as pectic acid liquefying activity.

\begin{tabular}{|c|c|c|}
\hline Compound & $\begin{array}{l}\text { Concentration } \\
(\mathrm{mM})\end{array}$ & $\begin{array}{l}\text { Relative } \\
\text { activity }\end{array}$ \\
\hline None & - & 100 \\
\hline \multirow[t]{2}{*}{$\mathrm{AgNO}_{3}$} & 0.1 & 87 \\
\hline & 1.0 & 44 \\
\hline $\mathrm{Ba}\left(\mathrm{CH}_{3} \mathrm{COO}\right)_{2}$ & 1.0 & 100 \\
\hline $\mathrm{CaCl}_{2}$ & 1.0 & 44 \\
\hline $\mathrm{CoCl}_{2}$ & 1.0 & 44 \\
\hline $\mathrm{CuSO}_{4}$ & 1.0 & 62 \\
\hline $\mathrm{EDTA}^{a}$ & 0.1 & 100 \\
\hline $\mathrm{FeCl}_{2}$ & 1.0 & 92 \\
\hline $\mathrm{KCl}$ & 1.0 & 108 \\
\hline $\mathrm{KCN}$ & 0.1 & 100 \\
\hline $\mathrm{LiSO}_{4}$ & 1.0 & 100 \\
\hline $\mathrm{MgSO}_{4}$ & 1.0 & 100 \\
\hline $\mathrm{MnCl}_{2}$ & 1.0 & 92 \\
\hline $\mathrm{NaCl}$ & 1.0 & 100 \\
\hline $\mathrm{NaN}_{3}$ & 0.1 & 100 \\
\hline $\mathrm{Pb}\left(\mathrm{CH}_{3} \mathrm{COO}\right)_{2}$ & 0.1 & 108 \\
\hline $\mathrm{SnCl}_{2}$ & 0.1 & 100 \\
\hline $\mathrm{ZnCl}_{2}$ & 0.1 & 100 \\
\hline \multirow[t]{2}{*}{ Iodoacetic acid } & 0.1 & 87 \\
\hline & 1.0 & 84 \\
\hline \multirow[t]{2}{*}{ Mersalyl acid } & 0.05 & 70 \\
\hline & 0.1 & 45 \\
\hline \multirow{3}{*}{$\begin{array}{l}p \text {-Chloromer- } \\
\text { curibenzoic acid }\end{array}$} & 0.01 & 100 \\
\hline & 0.05 & 73 \\
\hline & 0.1 & 15 \\
\hline $\begin{array}{l}p \text {-Chloromercuri- } \\
\text { phenylsulfonic } \\
\text { acid }\end{array}$ & 0.1 & 93 \\
\hline
\end{tabular}

activity (pectic acid liquefying activity) were determined at $\mathrm{pH}$ 5.0. As shown in Table $\mathrm{I}$, the enzyme activity was inhibited by such metal ions as $\mathrm{Ag}^{2+}, \mathrm{Ca}^{2+}, \mathrm{Co}^{2+}, \mathrm{Cu}^{2+}, \mathrm{Hg}^{2+}$ and $\mathrm{Hg}^{+}$.

\section{Action of the enzyme on oligogalacturonic acids}

The enzyme activity on the hydrolysis of galacturonic acid oligomers was determined. Figure 5 shows thin layer chromatograms of products of the enzyme reaction with tetraand pentagalacturonic acid. Trigalacturonic acid and digalacturonic acid were the reaction products of pentagalacturonic acid, and galacturonic acid and its dimer were the reaction 


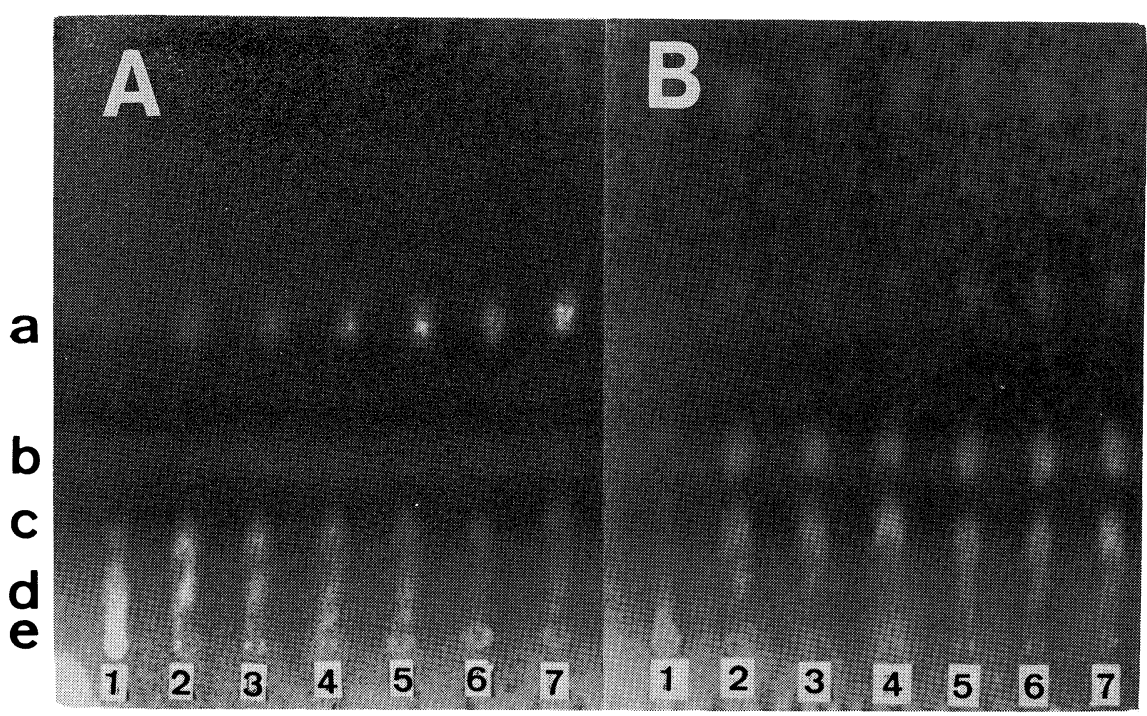

FIG. 5. Thin Layer Chromatograms of the Time Course of Hydrolysis of Tetra- and Pentagalacturonic Acid by the Enzyme.

Reaction mixtures contained $20 \mathrm{mg}$ of the respective oligogalacturonic acid in $0.4 \mathrm{ml}$ of $0.02 \mathrm{M}$ acetate buffer, $\mathrm{pH} 5.0$, and $0.1 \mathrm{ml}$ of the enzyme solution (containing $2 \mu \mathrm{g}$ of enzyme), and reactions were performed at $37^{\circ} \mathrm{C}$ for the indicated periods $(1,0 ; 2,2 ; 3,6 ; 4,15 ; 5,30$; and $6,100 \mathrm{~min}$, respectively). After incubation, $50 \mu 1$ of a reaction mixture was mixed with $0.05 \mu \mathrm{l}$ of $1 \mathrm{~mm}$ mercurous acetate solution to stop the reaction and a $2 \mu \mathrm{l}$ aliquot was subjected to thin layer chromatography.

A, chromatogram of the reaction products with the enzyme from tetragalacturonic acid; B, chromatogram of the reaction products with the enzyme from pentagalacturonic acid.

$\mathrm{a}, \mathrm{b}, \mathrm{c}, \mathrm{d}$, and $\mathrm{e}$ indicate the positions of galacturonic acid, its dimer, trimer, tetramer and pentamer, respectively.

Table II. Kinetic Properties of the Enzyme

The reaction mixture was composed of 0 to $200 \mu \mathrm{mol}$ substrate, $10 \mathrm{mmol}$ acetate buffer, pH 5.0 , and enzyme solution ( 0.5 units for polygalacturonic acid, 5 units for pentagalacturonic acid, 20 units for tetra- and trigalacturonic acid and 50 units for digalacturonic acid, respectively) in a total volume of $2.0 \mathrm{ml}$, and the reaction was carried out at $37^{\circ} \mathrm{C}$ for 5 and $10 \mathrm{~min}$ for polygalacturonic acid, 5 and $10 \mathrm{~min}$ for pentagalacturonic acid, 60 and $90 \mathrm{~min}$ for tetragalacturonic acid and 90 and $180 \mathrm{~min}$ for trigalacturonic acid, respectively.

\begin{tabular}{lcc}
\hline Substrate & $\begin{array}{c}\text { Michaelis } \\
\text { constant } \\
(\mathrm{mM})\end{array}$ & $\begin{array}{c}\text { Maximal velocity } \\
(\mu \text { mol } / \text { mg protein } / \text { min })\end{array}$ \\
\hline Digalacturonic acid & Not reacted in $24 \mathrm{hr}$ & \\
Trigalacturonic acid & 4.26 & 2.76 \\
Tetragalacturonic acid & 2.20 & 300 \\
Pentagalacturonic acid & 0.87 & 1644 \\
Polygalacturonic acid & 0.04 & 13386 \\
(containing 270 galacturonic acid residues) & & \\
\hline
\end{tabular}

products of tetragalacturonic acid. Galacturonic acid and its dimer were formed by the reaction with trigalacturonic acid. However, degradation of digalacturonic acid by the enzyme was not observed.
As shown in Table II, listing the $\mathrm{Km}$ and $V_{\max }$ values, the rate of hydrolysis catalyzed by the enzyme decreased with shortening of the oligogalacturonic acid chain-length. Trigalacturonic acid was the lowest oligogalac- 
turonic acid which was hydrolyzed by the enzyme, and it was hydrolyzed extremely slowly; Its $V_{\max }$ was approximately two orders lower than that of tetragalacturonic acid.

Relationship between the methoxyl group content of the substrate and the molecular weight of its degradation products with the enzyme

The effect of the methoxyl group content of the substrate on the polymerization degree of the reaction product was investigated using polygalacturonic acid with methoxyl groups of various numbers as the substrate, and the results are shown in Fig. 6. The plot of content of galacturonic acid with methoxyl groups (in percent) of the substrate was parallel to the logarithm of the polymerization degree of the reaction products.

Survey of amino acid residues participating in the enzyme reaction

In order to survey the amino acids participating in our enzyme reaction, some studies were performed.

The enzyme was inactivated by illumination of the enzyme solution in the presence of Methylene Blue, and loss of activity was observed to follow first order kinetics (Fig. 7), but not with either both Methylene Blue or illumination alone. The rates of photoinactivation in the presence of Methylene Blue were $\mathrm{pH}$-dependent and remaining activity versus $\mathrm{pH}$ is shown in Fig. 8, and the $\mathrm{p} K$ value was calculated to be around $\mathrm{pH}$ 6.1. The $\mathrm{pH}$ dependence of the photoinactivation indicated that an amino acid residue which dissociated around $\mathrm{pH} 6.1$ was essential for the enzyme's active site. This was an indication that a histidyl residue might be being photo-oxidized, since the dye-sensitized photo-oxidation of histidine has been shown to be sharply $\mathrm{pH}$ dependent, the protonated form being resistant to oxidation. ${ }^{10)}$ In order to confirm this supposition, investigations were done on the relationship between enzyme activity lost and decomposed amino acids which are known to be sensitive to photo-oxidation. The photooxidized enzyme solution was dialyzed thoroughly against distilled water, hydrolyzed in $6 \mathrm{~N} \mathrm{HCl}$ containing $3 \%$ thioglycollic acid in

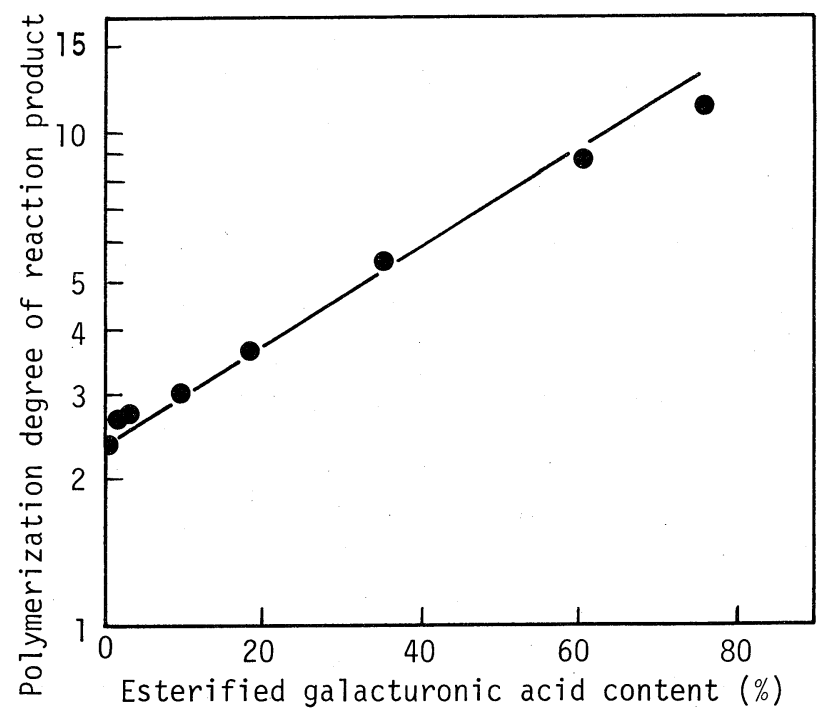

FIG. 6. Relationship between Methoxyl Groups of the Substrate and the Molecular Weight of Its Degradation Product with the Enzyme Reaction.

Reactions were performed under the standard assay conditions using polygalacturonic acid (mean polymerization degree, 33) containing the various numbers of methoxyl groups indicated. Polymerization degrees were determined from the ratio of total reducing groups to total galacturonic acid molecules. 


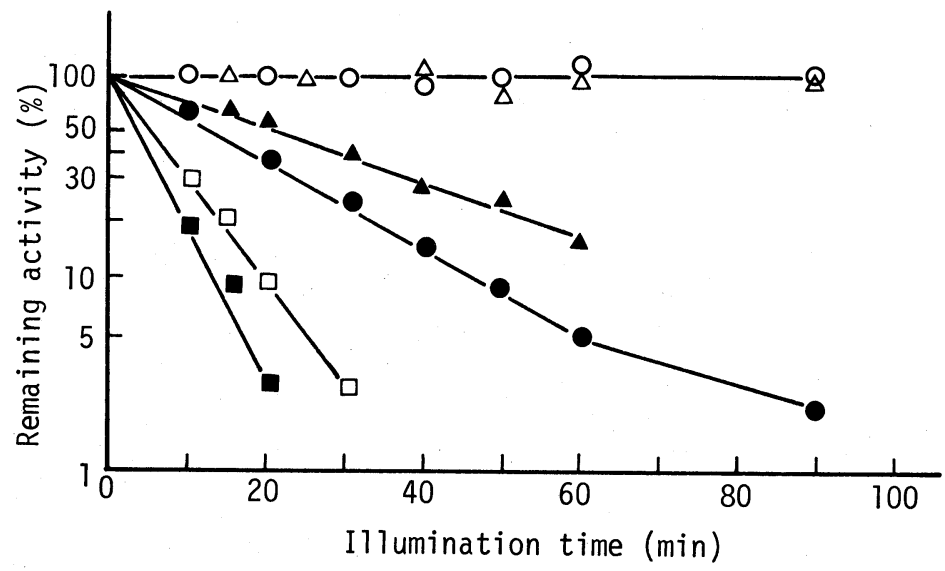

FIG. 7. Effect of $\mathrm{pH}$ of the Rates of Photoinactivation of the Enzyme in the Presence of Methylene Blue. Illumination of the enzyme solution was performed under the conditions given in MATERIALS AND METHODS. Activity loss of the enzyme at pH $5.0(\mathbf{\square})$, pH $5.5(\square)$, pH $6.0(\mathbf{O})$ and $\mathrm{pH} 6.5(\boldsymbol{\Delta})$, in the absence of Methylene Blue $(\triangle)$ and when not illuminated $(O)$.

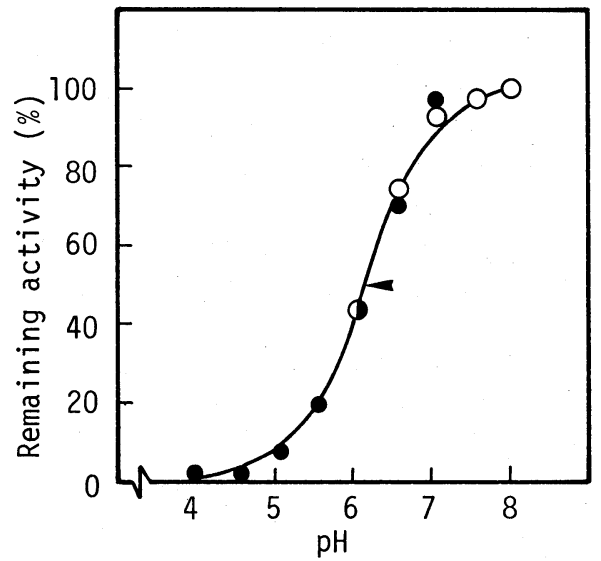

FIG. 8. The pH-Dependence of the Photoinactivation of the Enzyme.

Illumination of the enzyme solution was performed under the conditions given in Materials and Methods, using $0.1 \mathrm{M}$ citrate- $\mathrm{NaOH}$ buffer $(O)$, and $0.1 \mathrm{M}$ potassium phosphate buffer $(O)$. In the figure, an arrow indicates the $\mathrm{p} K$ value of photoinactivation of the enzyme.

a sealed tube filled with nitrogen gas at $100^{\circ} \mathrm{C}$ for $36 \mathrm{hr}$, and applied to the amino acid analyzer. The results are shown in Fig. 9. Tryptophan was found to be decomposed by photo-oxidation as well as histidine, whereas tyrosine (known as an amino acid decomposed by photo-oxidation) was not decomposed. Enzyme activity was lost parallel with the amount of histidine decomposed, but not with that of tryptophan (even though tryptophan

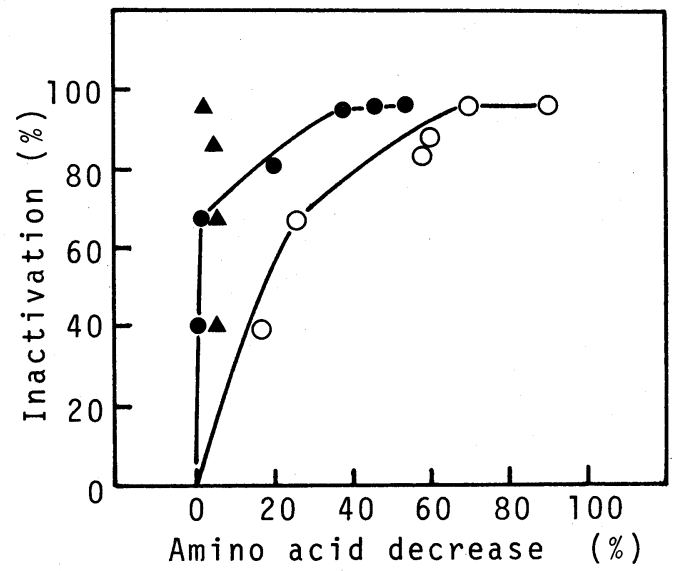

FIG. 9. Relationship between Decrease of Amino Acid and the Enzyme Activity on Photooxidation.

Illumination of the enzyme was performed under the conditions given in MATERIALS AND Methods up to 90 $\mathrm{min}$, and aliquots of the illuminated enzyme solution were dialyzed against distilled water, hydrolyzed in $6 \mathrm{~N} \mathrm{HCl}$ containing $3 \%$ thioglycollic acid in a sealed tube filled with nitrogen gas at $100^{\circ} \mathrm{C}$ for $36 \mathrm{hr}$ and applied to an amino acid analyzer. ( $\boldsymbol{\Delta})$, tyrosine; (O), tryptophan; $(\bigcirc)$, histidine.

was not decomposed, about $70 \%$ of the initial enzyme activity was lost).

\section{Effect of galacturonic acid or its oligomers on the enzyme activity}

The effects of galacturonic acid or its oligomers on protopectinase and pectic acid 


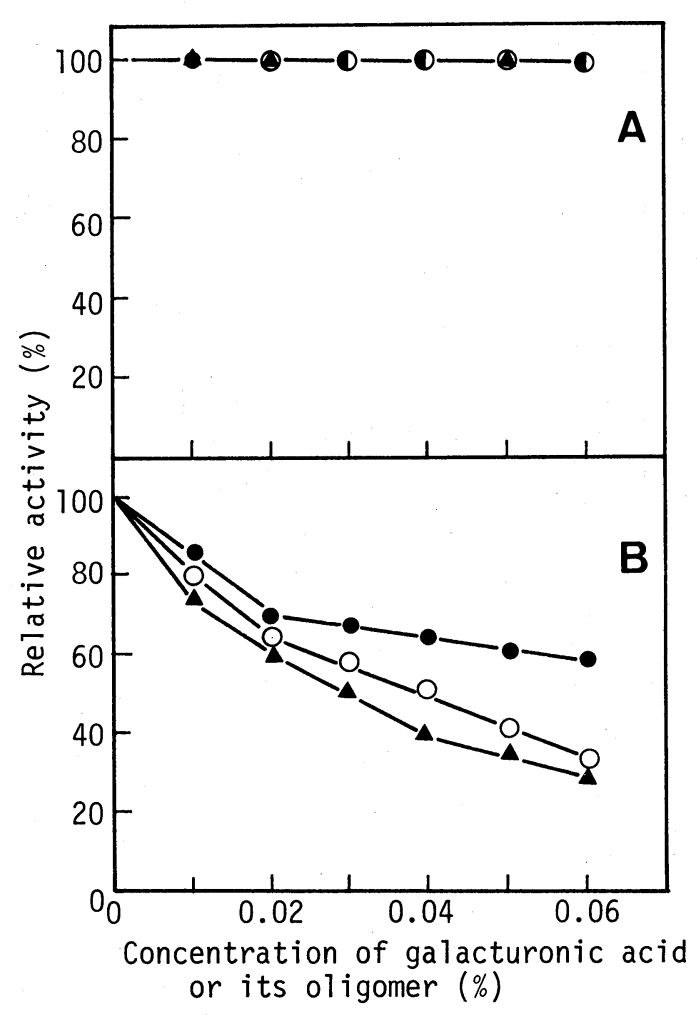

FIG. 10. Effect of Galacturonic Acid or Its Oligomers on the Enzyme Activity.

The reaction was performed under the standard assay conditions except that galacturonic acid ( $(\mathbf{)})$, digalacturonic acid $(O)$ or trigalacturonic acid $(\boldsymbol{\Delta})$ was added as indicated.

A, effect on protopectinase activity; B, effect on pectic acid liquefying activity.

liquefying activity were determined. As shown in Fig. 10, pectic acid liquefying activity was inhibited by galacturonic acid and its dimer and trimer, whereas protopectinase activity was not inhibited.

\section{DISCUSSION}

As our enzyme is intended to be used for industrial purposes, the effects of $\mathrm{pH}$ and temperature on activity and stability of the enzyme were investigated, first. Although the optimal $\mathrm{pH}$ of the enzyme reaction varies depending upon the substrate used (pectic acid and protopectin were used as substrates), they lie around $\mathrm{pH}$ 5.0. These properties are favor- able for practical use, because the enzyme is to be used in pectin production and pectin is most stable around $\mathrm{pH}$ 5.0. The enzyme is stable at acidic $\mathrm{pHs}$ ( $\mathrm{pH} 3$ to 6 ) up to $50^{\circ} \mathrm{C}$. However, the stability of pectic acid liquefying and that of protopectinase activity are different at higher than $\mathrm{pH} 7.0$; pectic acid liquefying activity

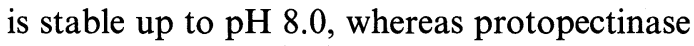
activity is lost higher than $\mathrm{pH}$ 7.0. We suppose that the enzyme has a site having affinity to protopectin and a site that is labile at alkaline $\mathrm{pH}$. However, we did not study this problem further.

Most polygalacturonases have optimal $\mathrm{pHs}$ in the weakly acidic region between $\mathrm{pH} 4.0$ and 6.5. ${ }^{11 \sim 14)}$ Endo-polygalacturonase from Saccharomyces fragilis shows a $\mathrm{pH}$ optimum with pectic acid at $\mathrm{pH} 4.4$, whereas with oligogalacturonic acids the $\mathrm{pH}$ optimum is around $\mathrm{pH} 3.5 .^{15)}$ A similar shift of $\mathrm{pH}$ optimum is observed with other endopolygalacturonases. ${ }^{16 \sim 18)}$ With our enzyme, the $\mathrm{pH}$ optimum is different with pectic acid than with protopectin as a substrate. However, the mechanism of the shift of $\mathrm{pH}$ optimum was not studied.

The enzyme catalyzes the hydrolysis of galacturonic acid oligomers; pentagalacturonic acid is degraded to tri- and digalacturonic acid, tetragalacturonic acid to trigalacturonic acid and galacturonic acid, and trigalacturonic acid to digalacturonic acid and galacturonic acid, respectively, whereas digalacturonic acid is not degraded further.

Three different patterns of action towards galacturonic acid oligomers are known for endo-polygalacturonases. ${ }^{19)}$ This enzyme is novel in the criterion of action patterns towards oligogalacturonic acids.

The kinetic constant $V_{\max }$ and $K m$ values change with the substrate chain-length; the $\mathrm{Km}$ values tend to decrease, whereas the $V_{\max }$ values tend to increase with increasing chainlength of the substrate. A great difference in $V_{\max }$ was found between trigalacturonic acid and tetragalacturonic acid. On the other hand, it was found that the methoxyl group content of the substrate affects the molecular weight of 
the reaction products; the molecular weight of the reaction products increases in accordance with the increasing galacturonic acid with methoxyl groups of the substrate. As mentioned in the preceding paper, our enzyme reacts with protopectin and releases high molecular weight pectin (protopectinase activity). On the basis of these results, we assume the mechanism of protopectinase activity of the enzyme to be as follows: The enzyme reacts with the pectin molecule in protopectin at sites having more than three nonmethoxylated-galacturonic acid-chains (realistically more than four nonmethoxylated-galacturonic acid chains, considering the reaction velocities for galacturonic acid oligomers) and splits their glycoside bonds. Generally, 50\% of the galacturonic acid of pectin in protopectin is methoxylated at random. Therefore, the pectin molecule in protopectin may be split at restricted sites, so as to form high molecular weight pectin. Moreover, as shown in Fig. 10, galacturonic acid, its dimer and trimer, which may be produced in the protopectinase reaction, all inhibit pectin degradation activity, whereas protopectinase activity is not inhibited, and the pectin molecules released from protopectin are protected from further degradation. Thus, our enzyme releases high molecular weight pectin from protopectin.

Many pectolytic enzymes, including endopolygalactuonase, pectin lyase and pectate lyase, are known to show maceration activity on various plant tissues. Our enzyme showed maceration activity on potato tissue but not on citrus peel. This phenomenon seems to indicate the diversity of plant tissues. From this we assumed that protopectinase activity does not always accompany maceration activity. However, details of this problem remain to be clarified.

Some studies on the amino acids participating in the active sites of endo-polygalacturonases have been published. On the basis of the effect of $\mathrm{pH}$ on the activity of Aspergillus niger endo-polygalacturonase, Koller $^{20)}$ considered that essential groups for the active site are the imidazole group of the histidine and the carboxyl groups of the glutamic acid or aspartic acid residues of the enzyme. After that, Rexová-Benková and Slezárik ${ }^{21,22)}$ showed that the inactivation of the enzyme was paralleled by the decomposition of histidine and indicated that one of the five histidine residues present in the enzyme molecule was essential for its activity.

In the present study, similar results to those of Rexová-Benková and Slezárik were obtained. Namely, the enzyme is inactivated by photo-oxidation in the presence of Methylene Blue, and the inactivation of the enzyme is paralleled by the decomposition of histidine in the enzyme molecule. These facts indicate that a histidine residue is essential for the activity of our enzyme.

\section{REFERENCES}

1) T. Sakai and M. Okushima, Agric. Biol. Chem., 42, 2427 (1978).

2) T. Sakai, Hakkô to Kôgyô, 37, 928 (1979).

3) T. Sakai and M. Okushima, Appl. Environ. Microbiol., 39, 908 (1980).

4) T. Sakai and M. Okushima, Agric. Biol. Chem., 46, 667 (1982).

5) C. W. Nagel and T. M. Wilson, J. Chromatogr., 41, 410 (1969).

6) J. A. Cifonelli and F. Smith, Anal. Chem., 26, 1132 (1954).

7) M. Somogyi, J. Biol. Chem., 195, 191 (1952).

8) N. Nelson, J. Biol. Chem., 153, 373 (1944).

9) O. H. Lowry, N. J. Rosebrough, A. L. Farr and R. J. Randall, J. Biol. Chem., 193, 265 (1951).

10) E. W. Westhead, "Methods in Enzymology," Vol. 25B, ed. by S. P. Colowick and N. O. Kaplan, Academic Press Inc., New York, N. Y., 1972, p. 401.

11) A. H. Fielding and R. J. Byrde, J. Gen. Microbiol., 58, 73 (1969).

12) M. C. Wang and N. T. Keen, Arch. Biochem. Biophys., 141, 749 (1971).

13) S. Ishii and T. Yokotsuka, Agric. Biol. Chem., 36, 1885 (1972).

14) H. Kimura and S. Mizushima, Agric. Biol. Chem., 37, 2589 (1973).

15) A. L. Demain and H. J. Phaff, J. Biol. Chem., 210, 381 (1954).

16) P. J. Mill and R. Tuttobello, Biochem. J., 79, 57 (1961).

17) I. Barash and Z. Eyal, Phytopathology, 60, 27 (1970).

18) R. Pressey and J. K. Avants, Plant Physiol., 52, 252 
(1973).

19) L. Rexová-Benková and Markovič, $A d v$. in Carbohydrate Chem. and Biochem., 33, 323 (1976).

20) A. Koller, Dissertation No. 3774, ETH, Zürich (1966).
21) L. Rexová-Benková and A. Slezárik, Collect. Czech. Chem. Commun., 33, 1965 (1968).

22) L. Rexová-Benková and A. Slezárik, Collect. Czech. Chem. Commun., 35, 1255 (1970). 